\title{
Presenças, ausências e (in)visibilidades de um texto: a escrita (experimental) da cegueira de um corpo que vê
}

\author{
Rodrigo Gonçalves dos Santos ${ }^{i}$ \\ Universidade Federal de Santa Catarina
}

\begin{abstract}
RESUMO
Minha abordagem durante todo este texto acolhe a possibilidade de um corpo do outro que vejo, assim como suas palavras que ouço, são dados a mim como imediatamente presentes em um campo. Desta forma, me presentifico à sua maneira, aquilo a que nunca estarei presente, que me será sempre invisível, de que nunca serei testemunha direta, uma ausência, portanto. Será que isso predestina o outro a ser espelho de mim mesmo, assim como eu sou o espelho dele? O outro - aquele que me lê (texto, escritura e autor) - faz com que eu mesmo tenha, de alguém ou de mim, uma única imagem, na qual eu e o outro estejamos implicados: quem me lê e quem é lido?
\end{abstract}

Palavras-chaves: alteridade, escrita, fenomenologia, arte.

\section{Abstract}

My approach throughout this text involves the possibility of a body to the other that I see, as well as his words which I hear, they are given to me as immediately present in a field. Thus, I present myself in its way, that which I will never be present, that will always be invisible to me, of which I will never be a direct witness, therefore an absence. Does this predestines the other to be the mirror of myself as I am their mirror? The other - the one who reads me (text, writing and author) - allows me to have, from someone or from myself, a single image in which $I$ and the other are involved: who reads me and who is read?

Keywords: otherness, writing, phenomenology, art.

\section{(Fragmento inicial) Tempo Um: um Diário de Bordo no bolso do pesquisador}

Há tempos visitava aquela biblioteca. Milhares de livros nas estantes, cada uma com meticulosa classificação a qual parecia um mapa de tão bem esclarecedora. Nunca me perdi ao tentar encontrar algum livro. Na realidade, me perdia em meio aos autores dos livros e me detinha em suas histórias de vida, suas fotografias. Nunca fui habituado a ler biografias, mas os prefácios dos livros, esses sim me prendiam atenção. Saber como os livros foram feitos, as situações em que foram escritos, os contextos das escritas... Às vezes tirava as tardes apenas para ler os prefácios. Até hoje não me arrependo. Em cada prefácio eu me construía também e (por que não?) sentia em minha pele as circunstâncias que conduziam as escritas daquilo que estava lendo.

As minhas visitas àquela biblioteca eram, para mim, quase um culto diário. Ia de bicicleta. Pedalando eu já preparava meu corpo para assimilar as histórias e teorias que iria encontrar. Por vezes eu já ia com livros pré-escolhidos e era só encontrá-los nas

Revista Digital do LAV - Santa Maria - vol. 9, n. 2, p. 219 - 244. - mai./ago. 2016 ISSN 1983 - 7348 http://dx.doi.org/10.5902/1983734822256 
estantes. Por outras vezes eu deixava ao acaso e passeando entre as estantes sacava um livro e me colocava a lê-lo.

Certa tarde, após deixar minha bicicleta devidamente segura em frente à biblioteca, segui a uma estante que até então me havia passado desapercebida. Nela existiam livros velhos com capas duras, alguns parecendo cadernos de anotações ou diários. Um me chamou atenção. Sua capa era dura e tinha uma sobrecapa branca com bonitos desenhos florais em baixo relevo. Também em baixo relevo lia-se $A$ percepção de Outrem e o Diálogo em letras ornadas entrelaçando-se com os motivos florais. A sobrecapa estava em alguns pontos grudada à capa e se tentássemos tirá-la rasgava-se um pouco da capa e um pouco da sobrecapa. Lembrei-me de uma história sobre a túnica de Nessus a qual aderia ao corpo de quem a usasse arrancando-lhe a pele caso se tentasse tirá-la.

Pus-me a ler o livro, obviamente pelo prefácio. O prefácio era uma advertência. Ou melhor, o livro nem livro era. O prefácio-adevertência advertia-me que eu estaria lendo um diário, e que neste diário eu mergulharia numa íntima relação acerca da percepção de outrem e do diálogo. Fui invadido por uma curiosidade e prossegui a leitura. Um diário é algo que me desperta indagações sobre a existência humana. Como um diário tem a capacidade de se comunicar conosco? Que histórias se escondem na história descrita pelo diário? A ideia de ler o diário de outrem excitou-me porque eu também tenho um diário. E se alguém o encontrasse leria nele partes de minha trajetória de vida.

Voltando ao prefácio-advertência, descobri que o diário era de um Escritor e Filósofo nascido em 14 de março de 1908 em Rochefort e morto em 4 de maio de 1961 em Paris. Este escritor foi líder do pensamento fenomenológico na França, e o diário que estava lendo possuía partes de anotações que transitaram em vários de seus livros e escritos de maior repercussão. Ainda como advertência, era-me lembrado que o diário ficou inacabado e muitas páginas possuiam lacunas, rasuras, palavras e frases ilegíveis. Logo pensei: tal como é nossa vida em alguns momentos. O prefácio-advertência não foi escrito pelo autor do diário. Na realidade, o diário, propositalmente, não tinha as primeira páginas escritas e quem o encontrou, após a morte de seu autor, escreveu o prefácio o qual além de ser uma advertência era também um belíssimo epitáfio.

Nas páginas seguintes do Diário do Escritor e Filósofo deparei-me com a situação que eu estava vivenciando. Estranha coincidência que me tocou e me relembrou as experiências que estavam sendo vividas por mim e que pareciam terem sido vividas também pelo Escritor e Filósofo autor do diário. Destaco que a primeira coincidência foi que eu também deixei as primeiras páginas de meu diário em branco. Sempre tenho dificuldades 
de começar um caderno, ou neste caso um diário, escrevendo na primeira página. Sempre deixo uma "folga" de três páginas. Nunca soube explicar o porquê disso. Lendo o Diario do Escritor e Filósofo percebi que as páginas que deixei em branco serão futuramente meu epitáfio literário... Em meu diário, o qual chamo de Diário de Bordo, venho registrando uma experiência que assinala a percepção de outrem e um possível diálogo. Em meu Diário de Bordo tento colocar por meio de descrições somadas às minhas reflexões uma experiência realizada com cegos... Busco, assim, traçar paralelos entre o estudado e as minhas vivências junto àqueles que incitam a constante indagação que me acompanha há tempos: o que estou vendo? Confesso que não é uma tarefa fácil! Estamos aconstumados a sermos indiferentes perante à diversidade... Nesta experiência deparei-me com corpos diferentes, com percepções diferentes das que eu tenho. Tive contato com um outro muito diferente de mim.

\section{(Esta) escrita: breves notas epistemológicas}

Inicio pelo início por mais que ele pareça ser o fim. Eis um texto. Um texto que centra-se na angústia do olhar, da percepção. Traz consigo - num incidente, talvez - o (in)visível. Não se trata de um texto que fala de cegos ou de não-cegos. Se há um lugar de onde se ouve este texto, este lugar é o "entre". Logo, o texto está "entre" os cegos e os nãocegos. E o que emerge disto? Uma obra aberta... Opto por já de início situar este texto como uma obra aberta. Aberta para possibilidades de interpretações. Aberta para finalizar ciclos na mente de quem o lê. Aberta para convites de reflexões. É uma escritura que procura vir com seriedade e rigor científico envoltos na plasticidade das palavras, no rearranjo de frases, no entrelaçamento de letras. Talvez, um desenrolar de ideias que pairavam soltas e que decidiram tomar forma num texto. Será que elas encontrariam um lugar para serem lidas? Pode ser o início de uma tentativa...

Decidi encarar a ciência sobre outro prisma, e encontrei um respaldo em Maurice Merleau-Ponty. Assim como o autor, não quero polemizar e impor uma maneira de pensar um objeto de pesquisa. Gostaria de tentar coexistir com a ciência que por vezes se apresenta com uma supremacia objetiva a todos nós. Não quero assumir, nas palavras de Merleau-Ponty (2004), um pensamento de sobrevôo como um pensamento do objeto em geral. Tenho a pretensão de que meu texto

torne a se colocar num "há" prévio, na paisagem, no solo do mundo sensível e do mundo trabalhando tais como são em nossa vida, por nosso corpo, não esse corpo possível que é lícito afirmar ser uma máquina de informação, mas esse corpo atual que chamo meu, a sentinela que se posta silenciosamente sob minhas palavras e sob meus atos. (MERLEAU-PONTY, 2004, p. 14) 
Percebo que se uma ciência se torna meramente objetiva ela se perde na positividade. Não gostaria que isto acontecesse novamente. Digo novamente pois em pesquisas anteriores essa foi minha angústia científica: a de fechar conceitos, encerrar discussões pela excessiva objetividade. Foi com Edmund Husserl que percebi que temos a verdade das coisas, mas não temos a verdade de nossa posse das coisas. Com isto reparo que as verdades científicas ficam a flutuar, ficam despossuídas, parecem não ser a verdade de ninguém. Com Merleau-Ponty e Husserl decidi que para ser totalmente científico, eu precisaria investigar as atividades estruturais subjetivas que operam na ciência. Este movimento exige algo mais complexo do que continuar seguindo fazeres formais enclausurados em gradientes num estado sólido. A exigência aqui é de entender gradientes fluidos, líquidos, gasosos... Estes gradientes podem parecer sem escrúpulos, por vezes heréticos. Mas a heresia científica desperta minha curiosidade e soa-me como um desafio.

A heresia científica a que me refiro talvez precise ficar bem esclarecida nestas breves notas epistemológicas. O que chamo de heresia é o ato de (re)aproximar do âmbito científico a possibilidade de investir numa fenda epistemológica, saindo de estruturas objetivas dominantes nas ciências e entrar numa nova instância reflexiva, a fenomenológica, a qual, de acordo com Sokolowski (2004), faz justiça às intencionalidades que exercemos, mas não tematizamos, em nossos esforços científicos anteriores. Meu texto, assim, procura vir com um modo ontológico de redução, no qual a fenomenologia é tida como uma ciência e um rigoroso e explícito empreendimento de autoconsciência. A fenomenologia parece-me, de fato, uma ciência mais concreta do que qualquer das investigações parciais. Sokolowski (2004) comenta que a ciência da fenomenologia complementa e completa outras ciências particulares, enquanto retém a elas e à sua validade, de modo que, bastante paradoxalmente, a fenomenologia é a mais concreta das ciências. Logo, a fenomenologia mostra como a ciência mesma é um tipo de manifestação, e consequentemente mostra a ingenuidade do objetivismo, ingenuidade por afirmar que o ser é indiferente à manifestação.

No entanto, Merleau-Ponty (1994) nos alerta que ainda não sabemos nada sobre o mundo e o espaço objetivos! Vejo que para aguçarmos nossa sapiência (adormecida) sobre o mundo e o espaço objetivos precisamos descrever o fenômeno do mundo. Merleau-Ponty (1994) solicita-nos descrever o nascimento do mundo para nós num campo onde cada percepção torna a nos colocar, onde ainda estamos sós, onde os outros só aparecerão mais tarde, onde o saber e, particularmente, a ciência ainda não reduziram e nivelaram a perspectiva individual. É por meio desta perspectiva individual que devemos ter acesso ao mundo, portanto, em primeiro lugar, é preciso descrevê-la. 
Munido deste proceder (científico) investigo sobre a percepção daquilo que supomos ver. Descrevo um olhar deslocando-se num espaço-tempo, gerando momentos transversais no campo de meu trabalho. Descrevo o que estamos vendo, o que poderíamos ver, o que não vemos. Desloco percepções. Transpasso histórias procurando gerar uma narrativa visual sem imagens, ou melhor, com muitas imagens que (ainda) não são vistas, mas que estão procurando um território para coexistirem "entre" elas próprias e "entre" mim.

Mas a coexistência, que com efeito define o espaço, não é alheia ao tempo, ela é a pertença de dois fenômenos à mesma vaga temporal. Quanto à relação entre o objeto percebido e minha percepção, ela não os liga no espaço e fora do tempo: eles são contemporâneos. (...) A percepção me dá um "campo de presença" (MERLEAU-PONTY, 1994, p. 358).

É por esta razão que meu texto exige uma escritura. Uma escritura que é uma espécie de laboratório. Jacques Derrida coloca que "o tempo da escritura já não segue a linha dos presentes modificados. O futuro não é um presente futuro, ontem não é um presete passado" (DERRIDA, 2009, p. 434). Assim, meu texto não é linear, bem como seu processo de escritura. Início e fim mesclam-se. Deslocam-se. Neste sentido, coloco transversalmente em meu texto descrições de As cidades invisíveis de Italo Calvino, por serem tais cidades aquelas que traduzem lugares os quais descrevem o inesgotável existir humano. É uma licença que tomo para acionar potências latentes do ser no mundo... É um compromisso que assumo junto com Derrida (2009). Por meio destas transversalidades textuais trago uma escritura de origem, escritura descrevendo a origem, assinalando os sinais do seu desaparecimento, escritura apaixonada pela origem.

A escritura, paixão da origem, deve entender-se também pela via do genitivo. É a própria origem que é apaixonada, passiva e suscetível de ser escrita. O que quer dizer inscrita. A inscrição da origem é sem dúvida o seu ser-escrito, mas é também o seu ser-inscrito num sistema do qual não passa de um lugar e de uma função (DERRIDA, 2009, p. 429).

Pode ser uma escritura que excita. É uma excitação nos moldes de Merleau-Ponty (1994), a qual é apreendida e reorganizada por funções transversais que a fazem assemelhar-se à percepção que ela vai suscitar. E fica claro, mais uma vez, o porquê da escolha pela descrição fenomenológica como fio condutor de minha escritura. "Essa forma que se desenha no sistema nervoso, esse desdobramento de uma estrutura, não posso representá-los como uma série de processos em terceira pessoa, transmissão de 
movimento ou determinação de uma variável por outra" (MERLEAU-PONTY, 1994, p. 114).

Entendo, ainda, que este texto espacializado por esta escritura pode ser traduzido por uma filosofia reflexionante. Destarte, parto do princípio de que, se uma percepcão deve poder ser minha, é preciso que, de agora em diante, seja uma de minhas representações. É o que Merleau-Ponty (2007) indica ao comentar que devemos ser como pensamento, efetuando a ligação dos aspectos sob os quais o objeto se apresenta com sua síntese num objeto.

É pela reflexão que o eu perdido em suas percepções se reencontra, reencontrando-as como pensamentos. Interrogo: Há preexistência do mundo diante de nossa percepção? Existem aspectos do mundo percebidos pelo outro diante da percepção que terei mais tarde de meu mundo e do mundo dos homens que vão nascer? Todos esses "mundos" constituem um mundo único no sentido em que as coisas e o mundo são objetos de pensamento com suas propriedades intrínsecas? É tomando emprestado a estrutura do mundo que se constrói para nós o universo da verdade e do pensamento?

A minha relação com o olhar do outro, esse olhar que lê meu texto, espacializa-se por meu próprio texto. Quero despertar no outro aquilo que é despertado em mim quando escrevo. O olhar de um outro sobre as coisas que faço reclama o que lhe é devido.

Com Merleau-Ponty (2007) pergunto: que aconteceria se eu contasse, não somente com minhas visões de mim mesmo, mas também com as que outrem teria de si e de mim? Assumo meu texto como se fosse o meu corpo no sentido merleau-pontyano. É um texto-corpo encenador de minha percepção, destruindo a ilusão de uma coincidência de minha percepção com as próprias coisas. Alerto que não é inteiramente meu texto-corpo que percebe. Entendo que meu texto-corpo pode impedir-me de perceber, mas não posso perceber sem sua permissão. No momento em que a percepção surge, meu textocorpo se apaga diante dela, e nunca ela o apanha no ato de perceber. Por sua vez,

esta reflexão do corpo sobre si mesmo sempre aborta no último momento: no momento em que sinto minha mão esquerda com a direita, correspondentemente paro de tocar minha mão direita com a esquerda. (...) a percepção não nasce em qualquer lugar, mas emerge no recesso de um corpo. (MERLEAU-PONTY, 2007, p.20-

21) [grifo meu].

Desloco mais uma vez... Na minha escritura aparece transversalmente outra escritura. Descrevo uma experiência de um olhar o corpo do outro para entender os termos que a 
escritura (oficial) apresenta. Poderia ser apenas uma história de uma vivência acerca do corpo-espaço-objeto de um outro que é, segundo Sacks (2007) vidente de corpo inteiro. Esta vivência é transversal assim como são as cidades invisíveis. Semelhanças entre elas podem ser traçadas, mas deixo-as para o(a) leitor(a) fazê-las, pois como já disse, este texto é uma obra aberta justamente para estas licenças "poéticas". Por que faço isto? Por que rompo com uma (pseudo)linearidade que é confortável aos olhos preguiçosos de um(a) leitor(a) desavisado(a)? É a incontinência de uma escritura... É um texto-corpo que implora por tais experiências de leitura. É a possibilidade de uma repetição, de uma morte, de uma origem que não reedita o texto, apenas o faz coexistir a cada manusear, a cada leitura.

A morte está na aurora porque tudo começou pela repetição. Logo que o centro ou a origem começaram por se repetir, por se redobrar, o duplo não se acresentava apenas ao simples. Dividia-o e fornecia-o. Havia imediatamente uma dupla origem mais a sua repetição. Três é o primeiro número da repetição. $O$ último também, pois o abismo da representação permanece sempre dominado pelo seu ritmo, ao infinito. Sem dúvida, o infinito não é uno nem nulo, nem inumerável. É de essência ternária (DERRIDA, 2009, p. 434).

Reformulo, então, minhas primeiras palavras destas breves notas epistemológicas. Eis, não um texto, mas três textos. São três textos que se entrelaçam, coexistem, mostramse e esconde-se, solicitam leituras. Um deles (o oficial?) é o mais incorpado, de maior visibilidade. Trata de termos pertinentes à fenomenologia e deslocados para interesses (escusos?) de quem articula a feitura da escritura. Neste texto recortes são costurados, espaços são habitados, relações intermediadas, conversas afinadas, criações discutidas. Perdi-me e encontrei-me neste emaranhado de reflexões no oceano da descrição fenomenológica.

Um outro texto é o que descreve As cidades invisíveis de Italo Calvino. É um texto de beleza poética, deixado sugestivamente ao longo do caminho do texto mais incorpado para gerar pausas, devaneios... São centros de devaneio... São como pedras entalhadas cuidadosamente em forma de bancos para descansar um viajante exausto pela leitura. Ali, naquele descanso, as reflexões surgem e voam como as sementes de uma flor de dente de leão sopradas pelo vento, migrando por todo a escritura do texto.

E um outro texto aparece na tentativa de articular tudo o que solidamente apresenta-se nos demais textos $A$ intenção é deixá-lo pairando no ar e sua entrada se dará em partes, aparecendo e desaparecendo oportunamente em pontos da escritura oficial. Ele logo será notado por sua situação de quase-ser. Nesta tentativa ele corre o risco de desmanchar- 
se, de parecer inacabado. Esta é a sua contribuição: seu inacabamento renova a leitura, traz a repetição do centro ou da origem, faz todo o texto e toda a leitura se redobrar.

E para que tudo isto? Como já disse no início, para investigar a percepção daquilo que supomos ver. Se realmente vemos, o que vemos? Se realmente não vemos, o que não vemos? A cegueira não é escuridão. A cegueira também não é invisibilidade. O que é a cegueira? É uma experiência perceptiva? Estas perguntas, nem sei se as respondo... No início de tudo (e no fim também) queria investigar a cegueira. Ledo engano! Acho que o verdadeiro cego era eu ao querer investigar uma das milhares maneiras de habitar um mundo. Será que esta maneira de habitar o mundo permite que eu também habite o mundo à minha maneira? Eis o critério de coexistência apresentado por Bourriaud (2009) e endossado por Merleau-Ponty. Eis o desafio maior. E do que escrevo, então? Sobre tudo isto... Sobre existir, sobre perceber como existir, sobre ver e não-ver como existir, sobre entrelaçamentos de existires, sobre encontros fortuitos num existir...

\section{Tecidos e colchas ao vento: o nascimento da escrita}

Presume-se que Isaura, cidade dos mil poços, esteja situada em cima de um profundo lago subterrâneo. A cidade se estendeu exclusivamente até os lugares em que os habitantes conseguiram extrair água escavando na terra longos buracos verticais: o seu perímetro verdejante reproduz o das margens escuras do lago submerso, uma paisagem invisível condiciona a paisagem visível, tudo o que se move à luz do sol é impelido pelas ondas enclausuradas que quebram sob o céu calcário das rochas.

Em consequencia disso, Isaura apresenta duas religiões diferentes. Os deuses da cidade, segundo alguns, vivem nas profundidades, no lago negro que nutre as veias subterrâneas. Segundo outros, os deuses vivem nos baldes que, erguidos pelas cordas, surgem nos parapeitos dos poços, nas roldanas que giram, nos alcatruzes das noras, nas alavancas das bombas, nas pás dos moinhos de vento que puxam a água das escavações, nas torres de andaimes que sustentam a perfuração das sondas, nos reservatórios suspensos por andas no alto dos edifícios, nos estreitos arcos dos aquedutos, em todas as colunas de água, tubos verticais, tranquetas, registros, até alcançar os cataventos acima dos andaimes de Isaura, cidade que se move para o alto.

(Italo Calvino, 1990, p. 24) 
Minhas avós trabalhavam com costura. Quando criança, por vezes, eu passava algumas tardes ora com uma, ora com outra, e observava a habilidade de um costurar fascinando meus olhos infantis. Uma avó utilizava uma máquina de costura a pedal, antiga, muito bonita e bem preservada. A agilidade com que ela pisava naquele pedal realizando um vai-e-vem ritmado com um barulho de agulha costurando fazia-me tecer viagens naqueles retalhos... Àqueles retalhos minha avó emprestava um pouco de sua vida e criava colchas maravilhosas, geometricamente arranjadas, com coloridos vibrantes e equilibrados, um verdadeiro quadro de retalhos. Por fim, ela costurava um fundo liso, fechando uma criação intuitiva... Lembro-me que ela não escrevia colcha em suas anotações de pedido... Ela escrevia corcha com uma letra muito bem desenhada tais como suas colchas. A mim me incomodava a escrita errada. Uma vez comentei com minha mãe e ela me pediu para não comentar nada, sequer rir daquele erro ortográfico. Hoje quando olho outras colchas de retalho (as que ela fazia não sobraram, ou pelo menos não "comprei" nenhuma...) lembro-me de cada corcha que presenciei nascer em sua máquina de costura.

Minha outra vó também utilizava retalhos em suas costuras. No entanto, diferente daquela avó, esta costurava sem máquina de costura. Fazia todas suas criações a mão. Sua especialidade eram bonecas, as quais ela nunca me deixou brincar: "isso não é coisa de menino, rapaz!". Às vezes ela fazia umas colchas, mas tais colchas tinham uma diferença que não sei precisar qual era. Mas eu gostava mesmo era de suas bonecas, e via nelas a graciosidade de um fazer preocupado com a vida da própria boneca. Minha mãe chamava esta bonecas de bruxas, mas eu as achava lindas, e não tinha nada de bruxa nelas. Lembravam-me a boneca Emília de Monteiro Lobato, tanto que eu sempre as chamava de Emília. A Emília Um, Emília Dois... Uma vez ela fez um sapo com olhos de pérolas que haviam caído de um colar, um cabelo de linhas vermelhas finas, e o recheou com arroz cru. "Para não ficar úmido", dizia ela. Este sapo ela me deu e, confesso, não vi a mesma beleza que via nas bonecas, mas vi nele um mar de possibilidades na sua tez de tecido preto com bolinhas brancas. Nunca dei um nome a ele, e ele era feito de poucos retalhos por ser pequeno...

Mas o que eu apreciava mesmo eram os retalhos! Variados tamanhos, variados tons, variadas texturas, variados cheiros... Aquilo era um mundo para mim... O barulho da tesoura cortando-os revelavam-me o barulho da criação. Se criar possui um som, seu som é de uma tesoura afiada cortando tecidos.

Desloco-me... Empunho uma tesoura... Corto meus tecidos... Tecidos de pesquisares... 
Neste exato momento, olho para minha caixa de retalhos. O que vejo nela? Retalhos variados, alguns pequenos, outros muito antigos cheirando a mofo, outros grandes e duros (como se estivessem engomados). Cada um com uma textura. Cada um pedindo para ser cortado... Este cortar me deixa apreensivo, pois significa que devo criar. E então? Seguro firme a tesoura e dou o primeiro corte...

Deslizo a tesoura... Relembro minhas avós... Assumo meus retalhos... Meu primeiro retalho: entender minha pesquisa, delinear minha escritura...

Há um estilo de escritura que implora por sair cada vez que posiciono-me para escrever. Devo dar vazão a este estilo? Esta é uma constante dúvida. A dúvida da aceitação da escritura... Confesso que depois de resistências iniciais, cedi, e fiz deste ceder a linha mestra de cada parágrafo, frase e palavra empregada no desenrolar deste texto. Tal como Merleau-Ponty (2007) esperei que a "ciência" (que até então eu presumia conhecer), encarada com um único conhecimento rigoroso, viesse me explicar qual seria o meu pesquisar. Entendia que o verdadeiro era o objetivo e quis determiná-lo mensurando-o, utilizando para tal empreendimento operações autorizadas que me cercassem variáveis trazendo uma (pseudo)ordem dos fatos, ordem e variáveis já previamente definidas por mim. Estava enganado? Creio que não. Era um território que eu já conhecia, já havia experimentado em outros pesquisares. Almejava um novo pesquisar... Queria eu mexer em meus retalhos, costurá-los com a agulha e a máquina de minhas avós. Desejava ver e tocar o (in)visível... Isto a ciência permitiria?

Eu percebia ao revirar minha caixa de retalhos científicos um "curioso" falar acerca da ciência:

Tais determinações nada devem a nosso contacto com as coisas: exprimem um esforço de aproximação que não teria sentido algum em relação à vivência, já que esta deve ser tomada tal qual, não podendo ser cosiderada "em si mesma". Assim, a ciência começou excluindo todos os predicados atribuídos às coisas por nosso encontro com elas. A exclusão, aliás, é apenas provisória: quando aprender a investi-lo, a ciência reintroduzirá a pouco e pouco o que de início afastou como subjetivo; mas integrá-lo-á como caso particular das relações e dos objetos que definem o mundo para ela (MERLEAU-PONTY, 2007, p. 25).

Assim, encorajei-me e decidi não excluir predicados, lançando olhares sobre a vivência e o subjetivo. Não queria exorcizar a "introspecção". Acredito ser possível reencontrar a clareza sem este exorcismo. 
Logo, dou menor importância à razões que impedissem de tratar a percepção como uma operação do sujeito, tal como nos sugere Merleau-Ponty em O visível e o invisível. Trago à tona reflexões que clarifiquem a tarefa de compreender em que sentido o que não é natureza forma um "mundo" e, antes de tudo, o que é um mundo; e, ainda, se há mundo, quais podem ser as relações entre o mundo visível e o mundo invisível.

Encaro, assim, que os estímulos da percepção são a causas do mundo percebido. Enfatizo, no entanto, que são estes estímulos que revelam tais causas ou as desencadeiam. E o mais importante assinalo agora: não falo aqui que se pode perceber sem corpo mas que é necessário reexaminar a definição de corpo como puro objeto para se compreender como pode ser nosso vínculo vivo com a natureza. Não quero apenas me estabelecer num universo de essências. Simplesmente peço que seja reconsiderado uma distinção da essência e das condições de existência, podendo, desta maneira, reportarme à experiência do mundo que precede minha própria existência. Empunhando a tesoura ao cortar meus retalhos acadêmicos e científicos quero estar onde aquele que questiona é, ele próprio, posto em causa pela questão.

É fundamental que haja reflexão! Retalhos soltos não configuram uma criação. Tal minhas avós, coloco-me a costurar com a linha da reflexão os retalhos que ora recorto. Neste costurar, vejo que além do próprio mundo, daquilo que somente é "em nós", do ser em si e do ser para nós, abre-se uma terceira dimensão onde desaparece discordâncias. O que vejo, então? Noto que perceber e imaginar nada mais são do que duas maneiras de pensar e é possível descrever esse pensamento, mostrar que é feito uma correlação rigorosa entre minha exploração do mundo e as respostas sensoriais que suscita. Reparo ainda que

percebemos a própria coisa, já que a coisa nada mais é do que aquilo que vemos, não, porém, pelo poder oculto de nossos olhos: eles não são mais sujeitos da visão, passaram para o número das coisas vistas, e o que chamamos visão faz parte da potência de pensar que atesta que esta aparência respondeu, segundo uma regra, aos movimentos dos olhos (MERLEAU-PONTY, 2007, p. 39).

Com o volume maior de retalhos à minha frente ponho-me a refletir. Juntamente com o primeiro retalho onde pretendia entender minha pesquisa e delinear minha escritura, somo outro retalho... Retalho mofado, mas de uma cor e textura fabulosas. Pergunto, por que está mofado? Vejo que eu o havia guardado muito no fundo de minha caixa de retalhos científicos e por poucas vezes o manuseava... Sua procedência? Não sei. Apenas sei que com ele vem um dogma no qual guarda tudo da fé perceptiva: a conviç̧ão de 
que há qualquer coisa, que há o mundo, a ideia de verdade, a ideia verdadeira dada. São convicções que prejudicam-me algumas vezes de ver o (in)visível. De entender aquilo que me é (in)visível. Mas, felizmente, vejo ao manusear este mofado retalho, que seu desagradável odor cede lugar a outro cheiro... Parece que o mofo não era bem um mofo, e veio ao meu olfato o cheiro da infância! Este era um retalho que herdei de minhas avós, e que Merleau-Ponty explicou-me em suas palavras:

A existência bruta e prévia do mundo que acreditava encontrar já ali, abrindo os olhos, é apenas o símbolo de um ser que é para si logo que é, porque todo o seu ser é aparecer e, portanto, aparece-se - e que se chama espírito (MERLEAU-PONTY, 2007, p.39).

E vou montando minha colcha (ou seria minha corcha?) cuidadosamente. Refletindo a cada corte. Observando cada costura. Escolhendo a melhor linha. Substituindo agulhas... Entregando-me a esta criação minuciosa, vejo que vou me liberando de falsos problemas suscitados por experiências bastardas e impensáveis. Vou compreendendo o que Merleau-Ponty (2007) diz ao se referir da simples transposição do sujeito encarnado em sujeito transcendental, e da realidade do mundo em idealidade. É o próprio MerleauPonty que vai me sugerindo atingir o mundo e o mesmo mundo, observando que este mundo é todo para cada um de nós, sem divisão, nem perda, porque é o que pensamos perceber. O mundo é o objeto indiviso de todos os nossos pensamentos e sua unidade, não sendo unidade numérica, não vem a ser a unidade específica.

$E$, inesperadamente, encontro um pequeno retalho com algo escrito nele (parecia a letra bem desenhada de minha avó). Era uma anotação de uma leitura. O retalho brindava-me com as seguintes palavras:

Eu, que estou no mundo, de quem aprenderia o que é estar no mundo se não de mim mesmo, e como poderia dizer que estou no mundo se não o soubesse? (MERLEAU-PONTY, 2007, p. 41)

Obriguei-me a fazer uma pausa... Mentalizei a colcha de retalhos que estaria fazendo... Não consegui ver a totalidade de minha colcha de retalhos... Deparei, assim, com o inacabamento... Assustei-me!

Lembrei-me que se existe um segredo do mundo ele deve estar contido em um contato com ele. Merleau-Ponty (2007, p. 41) afirma que "de tudo o que vivo, enquanto o vivo, tenho diante de mim o sentido, sem o que não o viveria e não posso procurar nenhuma luz, concernente ao mundo a não ser interrogando, explicando minha frequentação do mundo, compreendendo-a de dentro". Aprofundo-me nesta ideia e entendo que para 
assimilar o que seja ver e sentir, devo parar de acompanhar o ver e o sentir no visível e no sensível, pois é daí que ambos se lançam. Neste lançamento, o ver e o sentir circunscrevem algo que vai além deles mesmos, um domínio que não ocupam e a partir do qual se tornam compreensíveis segundo seu sentido e sua essência.

Começo a visualizar a paisagem invisível que condiciona a paisagem visível da cidade de Isaura descrita por Italo Calvino em seu livro As cidades invisíveis. Quão intrigante é tal condição de condicionar estas paisagens!

E, assim, tais paisagens de Isaura, bem como as opiniões acerca das duas religiões de Isaura e dos lugares dos deuses em cada uma destas religiões, demonstram como cada percepção é mutável e somente provável, não passando de uma opinião. Mas, paradoxalmente, cada percepção, mesmo sendo "falsa", demonstra a pertencença de cada experiência ao mesmo mundo, seu poder igual de manifestá-lo, a título de possibilidades do mesmo mundo. A possibilidade de substituição de cada percepção por uma nova percepção revela uma forma de desautorização das coisas, indica que cada percepção é uma aproximação, ilusão, pensamento.

Meço a colcha que estou costurando, e ao vê-la ainda incabada, um turbilhão de pensamentos são acionados. Os deuses que vivem nos baldes de Isaura sorriem-me e vejo mais calmamente a possível corcha (ou colcha?) quase (in)acabada. Assim como Merleau-Ponty (2007), também afirmo que o espírito é o que pensa e o mundo é o que é pensado. Não posso conceber nem a imbricação de um no outro, nem a confusão de um com o outro. Tampouco concebo a passagem de um para o outro ou mesmo o contato entre eles. E é justo neste momento que me é revelado um pensamento que clarifica esta questão. Refletindo, eu acesso a um espírito universal. Neste acesso, longe de descobrir enfim o que sou desde sempre, há uma motivação que se dá pelo entrelaçamento de minha vida com as outras vidas. Ou melhor dizendo, um entrelaçamento de meu corpo com as coisas visíveis. A mesma motivação se dá também pela confrontação de meu campo perceptivo com o de outros e pela mistura de minha duração com as outras durações.

O (in)visível me ronda... Está sempre ali... (Re)vejo-o e sinto-o em todos os meus sentidos. Sei que o mundo é o que nós vemos, mas precisamos urgentemente aprender a ver o mundo. Precisamos o quanto antes nos igualarmos a esta visão pelo saber. Assim, tomaremos posse desta visão e começaremos a introspectar melhor as indagações de Merleau-Ponty (2007): o que é nós? O que é ver? Parece-me que desta forma estaríamos agindo como se nada soubéssemos, como se ainda tivéssemos muito o que aprender. 
Movo-me na atitude fenomenológica, o que me torna uma espécie de observador imparcial de cenas que passam a minha frente, transformo-me num espectador de um jogo. Ao me tornar um espectador não sou mais simplesmente participante no mundo. Com esta atitude contemplo o que é ser um participante no mundo e nas suas manifestações. No entanto, estou consciente de que as intencionalidades que contemplo - as convicções, dúvidas, suspeições, certezas e percepções que examino e descrevo ainda são minhas intenções. Eu não as perco; somente as contemplo. Tais intenções permanecem exatamente como eram, e seus objetos permanecem exatamente como estavam. Contnuando existindo com as mesmas correlações entre intenções e objetos ainda em vigor. Curiosamente, as mantemos todas apenas como são, eu as "congelo".

Nesta atitude fenomenológica prezo pela descrição como a linha deste costurar e pesquisar. E é com esta linha costurando retalhos de pesquisares que minha escritura se encontra à vontade, alça vôos, espacializa-se com cientificidade. É aqui que me encontro, converso com teorias e coso meu pesquisar assumindo e passeando entre-lacunas, deslocando-me entre-fissuras epistemológicas e possibilidades de criação. Noticio meu texto desta maneira... Convido leitores(as) assim... Primo por vivências, pelo outro, por aquilo que o outro vê e que eu não vejo - o (in)visível - e que está ali para ser (des)coberto.

Pergunto juntamente com Merleau-Ponty (2007) como nomear, como descrever esta vivência de outrem, tal como a vejo de meu lugar. A resposta emerge envolta em névoas, mostrando-me que

em algum lugar atrás desses olhos, atrás desses gestos, ou melhor, diante deles, ou ainda em torno deles, vindo de não sei que fundo falso do espaço, outro mundo privado transparece através do tecido do meu, e por um momento é nele que vivo, sou apenas aquele que responde à interpelação que me é feita (MERLEAU-PONTY, 2007, p. 22).

Estou convencido que este outro que me invade é todo feito de minha substância. Vejo suas cores, sinto sua dor, vivo seu mundo precisamente enquantos seus a partir das cores que eu vejo, das dores que eu tive, do mundo em que eu vivo. Uma súbita felicidade cúmplice se apodera de mim: aliviado percebo que meu mundo privado deixou de ser apenas meu. Um outro o maneja tornando-o uma dimensão de uma vida generalizada a qual se enxertou na minha.

E qual seria, assim, meu ponto de apoio da verdade? Seria a certeza injustificável de um mundo sensível comum a todos nós? Comporto-me como uma criança que percebe antes 
de pensar, que começa a colocar seus sonhos nas coisas, seus pensamentos nos outros, formando com eles um bloco de vida comum? À estas interrogações apenas insinuo que o mundo sensível é "mais antigo" que o universo do pensamento. O mundo sensível é visível e relativamente contínuo, e o universo do pensamento é invisível e lacunar. Isto me aponta que, num primeiro momento, o universo do pensamento não constitui um todo, e só se tem a sua verdade com a condição de apoiar-se nas estruturas canônicas do outro. Então, será que nossas certezas naturais repousam, no que respeita ao espírito e à verdade, sobre a primeira camada do mundo sensível, e que nossa segurança de estar na verdade e estar no mundo é uma só?

Ampliando a ideia de que o universo do pensamento é invisível e lacunar, indago sobre o sonho. O sonho não é observável e, quando examinado, é quase só lacunas... MerleauPonty (2007) destaca que isto, efetivamente, não liquida o problema de nosso acesso ao mundo, ao contrário, inicia este acesso, pois nos incita a saber como podemos ter a ilusão de ver o que não vemos e como os farrapos do sonho podem, diante do sonhador, ter o mesmo valor do tecido encerrado do mundo verdadeiro. Vem, assim, uma inconsciência de não ter observado podendo substituir a consciência de ter observado.

Visualizo a cidade de Zenóbia descrita em As cidades invisíveis de Italo Calvino. Presto muita atenção que qualquer habitante ao descrever uma vida feliz sempre imagina uma cidade como Zenóbia...

Agora contarei o que a cidade de Zenóbia tem de extraordinário: embora situada em terreno seco, ergue-se sobre altíssimas palafitas, e as casas são de bambu e de zinco, com muitos bailéus e balcões, postos em diferentes alturas, com andas que superam umas das outras, ligadas por escadas de madeira e passarelas suspensas, transpostas por belvederes cobertos por alpendres cônicos, caixas de reservatórios de água, cata-ventos, desdobrando roldanas, linhas e guindastes.

Não se sabe qual necessidade ou mandamento ou desejo induziu os fundadores de Zenóbia a dar essa forma à cidade, portanto não se sabe se este foi satisfeito pela cidade tal como é atualmente, desenvolvida, talvez, por meio de superposições do indecifrável projeto inicial. Mas o que se sabe com certeza é que, quando se pede a um habitante de Zenóbia que descreva uma vida feliz, ele sempre imagina uma cidade como Zenóbia, com suas palafitas e escads suspensas, talvez uma Zenóbia totalmente diferente, desfraldando 
estandartes e nastros, mas sempre construída a partir de uma combinação de elementos do modelo inicial.

Dito isto, é inútil determinar se Zenóbia deva ser classificada entre as cidades felizes ou infelizes. Não faz sentido dividir as cidades nessas duas categorias, mas em outras duas: aquelas que continuam ao longo dos anos e das mutações a dar forma aos desejos e aquelas em que os desejos conseguem cancelar a cidade ou são por esta cancelados.

(Italo Calvino, 1990, p. 36-37)

... e Zenóbia me traz a lembrança do olhar do outro. São olhares de outros que localizam a (in)visibilidade de uma vida feliz numa (outra) Zenóbia. Aqui, destaco que não é de um ponto do espaço que parte o olhar do outro. "O outro nasce a meu lado, por uma espécie de broto ou de desdobramento" (MERLEAU-PONTY, 2007, p. 65). Em Zenóbia, nem eu mesmo e nem os outros, teríamos em comum um mundo que fosse numericamente 0 mesmo. Em Zenóbia, poderíamos apenas reunir-nos na significação comum de nossos pensamentos, pensamentos estes de uma vida feliz na cidade (in)visível de Zenóbia.

Suspendo meu coser-pesquisar? Minha colcha (corcha?) encontra-se (in)acabada? Utilizei todos meus retalhos científicos? O olhar do outro sobre minha colcha revela algo (in)visível que se enreda em meu corpo e espacializa-se numa escritura conduzida por uma linha revelando pontos bem firmes e consistentes traduzindo uma criação sem lacunas, pontos-sem-nó, fios soltos?

Deixo a colcha ao vento e vejo que movimentos ele gentilmente irá sugerir ela fazer...

\section{(Fragmento intermediário) Tempo dois: meu empréstimo a outrem}

Afinal, que face tem o outrem? Por que esta nunca se apresenta? A ira de quem me agride, ira esta que vejo, efetivamente não existe? É uma cerimônia? Então o que vejo quando a ira se apodera de meu adversário o qual é meu outrem? Na mesa da biblioteca, com o Diário do Escritor e Filósofo em mãos, refleti. Retirei de minha bolsa o meu Diário de Bordo e, inveitavelmente, coloquei-o ao lado do Diário do Escritor e Filósofo. Abri uma página de cada diário e olhei-as. Ali vi em cada página uma escrita que revelava um corpo. Fiz um gesto de colocá-las exatamente no mesmo alinhamento, fazendo com que uma parecesse a continuidade da outra. Diferenciavam-se as letras e a cor das páginas, mas a essência que dali exalava pareciam afins. Abandonei este gesto e disse comigo mesmo: "Imagina! Quanta prepotência a minha! Comparar-me com o Escritor e 
Filósofo!" Mas o gesto teimou em se repetir, e pus-me a ler os dois Diários como se fossem um só.

O Escritor e Filósofo trazia-me em seu diário uma explicação àquilo que eu fazia e ainda faço. Em meu Diário de Bordo, a minha tentativa é um empréstimo de meu corpo a outrem. Seria isto possível? Eu queria que o outrem apenas sentisse meus músculos e a totalidade de meu corpo para, então, repetir, imitar-me. Desejaria, por meio deste empréstimo, que o corpo de outrem fosse uma réplica de mim mesmo? Esta réplica se situaria às margens do que vejo e escuto uma vez que esta réplica (não) sou eu?

\section{Olhar e ver: ausências e percepção}

Depois de marchar por sete dias através das matas, quem vai a Bauci não percebe que já chegou. As finas andas que se elevam do solo a grande distância uma da outra e que se perdem acima das nuvens sustentam a cidade. Sobe-se por escadas. Os habitantes raramente são vistos em terra: têm todo o necessário lá em cima e preferem não descer. Nenhuma parte da cidade toca o solo exceto as longas pernas de flamingo nas quais ela se apóia, e, nos dias luminosos, uma sombra diáfana e angulosa que se reflete na folhagem.

Há três hipóteses a respeito dos habitantes de Bauci: que odeiam a terra; que a respeitam a ponto de evitar qualquer contato; que a amam da forma que era antes de existirem e com binóculos e telescópios apontados para baixo não se cansam de examiná-la, folha por folha, pedra por pedra, formiga por formiga, contemplando fascinados a própria ausência.

(Italo Calvino, 1990, p. 73)

Como posso ser percebido? Essa foi uma indagação que fiz a mim mesmo quando fui à uma instituição que desenvolve atividades com cegos. Nesta intituição a maioria das pessoas que trabalha e transita por lá é cega, e não era a primeira vez que estava indo lá. Eu já havia agendado uma reunião com uma assistente social e ela estava me esperando. Quando cheguei fui devidamente anunciado e fiquei aguardando chegar o início do meu encontro com a assistente social. Na minha espera, passaram por mim várias pessoas, algumas que eu conhecia, outras que me eram estranhas. Mas, tanto as estranhas quanto as conhecidas, por serem cegas, não notaram minha presença ali. Foi então que comecei a exercitar algo para preencher minha espera. Decidi não me comunicar verbalmente com ninguém e, por mais antipático que isto poderia parecer, fiquei imóvel, sentado, esperando ser chamado à sala de reuniões. Naquele momento eu 
pensei comigo: "não estão me vendo mesmo... vamos ver no que vai dar". A única coisa que eu fazia era olhar cada pessoa que passava por mim.

Curiosamente, os cegos me viam... Eles percebiam que alguém estava lá e o meu olhar atraía a atenção deles. Naquele momento em que eu lançava um olhar sobre o cego, este automaticamente lançava seu olhar sobre mim também. Eu estava sendo percebido assim como eu percebia quem me percebia... Houve uma pessoa que chegou a vir em minha direção e sua bengala quase tocou meus pés, o seu olhar estava fixo em mim, e pensei que tal pessoa me perguntaria por que eu estava a olhando tanto. Pensei em falar algo, mas tal como uma criança que brinca de ficar muda, mantive meu jogo "infantil" e quis ver no que daria seu final. Esta pessoa parou e mudou de direção. Confesso que ela chegou a dar uma última olhada para mim antes de entrar numa sala. Minha presença estava sendo notada... Os cegos me viam e assim como eu me dispus a não falar nada, o mesmo nada me era devolvido por eles. Vou mais além: me comportei com um animal dentro de uma jaula a ser observado por todos. Duas meninas que estavam indo ao banheiro me olharam, comentaram entre si algo e entraram no banheiro. Ao saírem de lá me olharam novamente e riram um riso nervoso... Devem ter pensado: "que animal estranho! Não dá um pio, não emite um som!"

Esta minha experiência (infantil) de invisibilidade me trouxe a mente o que viria a ser um "perceber algo". Sempre achava que perceber estava atrelado ao ver... O meu escondeesconde com os cegos colocou-me a maior de todas as indagações que eu poderia já ter tido: O que é perceber e o que é ver? Merleau-Ponty nos fala que

Ver é entrar em um universo de seres que se mostram, e eles não se mostrariam se não pudessem estar escondidos uns atrás dos outros ou atrás de mim. Em outros termos: olhar um objeto é vir habitá-lo e dali apreender todas as coisas segundo a face que elas voltam para ele (MERLEAU-PONTY, 1994, p. 105).

Os cegos estavam entrando no universo em que eu estava me mostrando. O meu silêncio era este universo e por meio dele eu estava me mostrando a eles. Naquele instante de espera eu era um animal enjaulado numa brincadeira de silêncio, e este mesmo animal escondia-me daqueles que passavam perto de mim. Havia olhares sobre o ser que estava atrás deste animal enjaulado, e isto mostrava o quanto eu estava sendo visto! Os cegos me habitavam, apreendiam-me e, consequentemente, a minha antipatia muda voltava para eles assim como a mesma antipatia se evidenciava em mim, incomodando-me. 
Merleau-Ponty (1994) mostra-nos que nossa percepção chega a objetos, e o objeto, uma vez constituído, aparece como a razão de todas as experiências que dele tivemos ou que dele poderíamos ter. Com isto vem em minha mente uma questão: quando vejo, esse meu ver não é sempre a partir de algum lugar? Se estou sentado à mesa do escritório e dela vejo meus livros, estou vendo-os a partir da mesa. No entanto, quando digo que vejo os livros com meus olhos, quero exprimir uma certa maneira de ter acesso ao objeto. O que aparece aqui é o olhar, o qual é tão indubitável quanto meu próprio pensamento, tão diretamente conhecido por mim. Mas o que é este olhar? Nos cegos havia este olhar que exprimiam uma maneira de me acessar na minha brincadeira de ficar em silêncio. O desafio é, justamente, compreender como a visão pode fazer-se de alguma parte sem estar limitada em sua perspectiva.

Olhar e ver... Estes termos por vezes se entrecuzam e confesso não saber distingui-los... Vou decifrando o termo percepção, pois penso nele residir a possível resposta. Entendo que para a fenomenologia, a percepção consiste no presentar um objeto diretamente para nós, e esse objeto é sempre dado numa mistura de presenças e ausências, ou seja, quando um lado está dado, outros estão ausentes. Reforçando o que Merleau-Ponty (1994) nos diz, algumas partes do objeto ocultam outras partes. Por exemplo, a parte da frente esconde a parte de trás, a superfície esconde o interior. Podemos ampliar esta condição considerando que se o objeto é algo que ouvimos, então ouvir em um lugar exclui aspectos do som que estariam disponíveis em outro lugar. Superamos tais ausências desde que percamos presenças que temos, as quais, por sua vez, tornam-se ausentes. "Por entre essa dinâmica mistura de presença e ausência, por entre essa multiplicidade de manifestações, um e o mesmo objeto continua a manisfestar a si mesmo para nós" (SOKOLOWSKI, 2004, p. 75).

Vou mais além e mergulho neste decifrar a percepção. Decido, primeiramente, realizar um mergulho em apneia pois tenho que voltar à tona para respirar deste oceano tão vasto de possibilidades. Assim, ao descer os primeiros metros deste mergulho, encontro em Husserl (1996) um ponto pelo qual tomo impulso para ir mais fundo. Husserl (1996) diz que qualquer alteração casual da posição relativa daquele que percebe altera a própria percepção. Parece elementar que pessoas diferentes que simultaneamente percebem a mesma coisa nunca têm exatamente a mesma percepção. Mas aí surge uma dúvida crucial: para a significação do enunciado de uma percepção, diferenças do que está sendo percebido são irrelevantes?

Volto à tona deste meu mergulho em apneia e respiro. Nesta respiração rejuvenescedora, paro e reflito. Lembro-me que Husserl (1996) esclarece que exprimir uma percepção, o percebido como tal, não compete às palavras pronunciadas, mas a 
certos atos expressivos. Para Husserl (1996) expressão significa, uma expressão vivificada por seu sentido total, colocada numa certa relação com a percepção, a qual é dita expressa devido esta relação. Compactuo com o autor e assumo existir entre a percepção e as palavras pronunciadas um ato ou um complexo de atos. É na vivência da expressão, seja ou não acompanhada de percepção, que se tem uma relação intencional com algo objetal. Husserl enfatiza este ato mediador, dizendo que tal ato

deverá servir propriamente de ato doador de sentido, ele é próprio à expressão que atua com pleno sentido, a título de seu componente essencial, fazendo com que o sentido seja sempre idêntico, quer a ele se associe uma percepção comprovante ou não (HUSSERL, 1996, p. 37).

Seria o bastante, então, distinguir pura e simplesmente a percepção e a significação do enunciado de percepção? Não seria mais interessante reconhecer que nenhuma parte dessa significação reside na própria percepção? É necessário separar completamente a percepção que dá o objeto, do enunciado que o pensa e o exprime por meio do juízo? Estas perguntas são recorrentes quando consulto os escritos de Husserl...

Novamente preparo-me para mais um mergulho no oceano da compreensão da percepção. Agora com as ideias de Husserl (1996) elucidando minhas indagações, arrisco-me a dizer que a percepção também nos "dá" o objeto em diferentes graus de perfeição, em diferentes graus de "sombreamento". Há um caráter intencional da percepção o qual consiste no presentar, em oposição ao mero presentificar. "Como sabemos, esta é uma diferença interna dos atos e, mais precisamente, uma diferença quanto à forma da sua representação apreensiva (forma de apreensão)" (HUSSERL, 1996, p. 114). Geralmente, o presentar não constitui um verdadeiro estar presente, onde existe presença do objeto e, com ela, a perfeição da captação verdadeira. Uma coisa ao ser vista envolve uma mistura do presente e do ausente. Subjetivamente, nossa percepção, nossa visualização, é uma mistura composta de intenções cheias e vazias. A atividade de perceber também é uma mistura; partes intencionam o que está presente, e outras partes intencionam o que está ausente, os "outros lados" de um objeto (SOKOLOWSKI, 2004).

E, no fundo deste meu mergulho, observando os corais de cores vibrantes em movimentos suaves acompanhando as correntes marítimas, aproprio-me das palavras de Husserl (1996, p.134) e designo como percepção cada ato preenchedor que se perfaça ao modo de uma confirmadora apresentação da própria coisa, como intuição todo e qualquer ato preenchedor, e como objeto o seu correlato intencional. Sob este aspecto, 
há uma percepção sensível, na qual a coisa exterior nos aparece de uma só vez, desde que sobre ela cai nosso olhar, deixando-a presente.

Assim como o fluxo do oceano no qual estou mergulhado para compreender a percepção vai empurrando-me para mais uma subida para respirar, reparo que existe um fluxo contínuo de percepção. Este fluxo contínuo é a resposta que temos quando não nos contentamos com um só olhar sobre uma coisa e queremos olhá-la por todos os lados, tocando-a com os sentidos. Cada percepção singular desse fluxo já é uma percepção dessa coisa. Se vejo minha mesa de cima ou de baixo, vejo sempre minha mesa. É sempre uma mesma coisa que vejo, mesma não no sentido meramente físico, mas conforme o próprio visar das percepções.

Respiro... E decido aventurar-me ainda mais nos escritos de Edmund Husserl... E num único fôlego detive-me no Apêndice da Sexta investigação de suas Investigações lógicas.

$\mathrm{E}$, com os pulmões ainda cheios de ar, encontro um aprofundamento acerca da percepção o qual não havia pensado. Vi claramente uma distinção entre o perceber algo que não sou eu, que me é externo; e em perceber algo inerente ao meu eu.

Ao fim deste meu ousado fôlego aventureiro de examinar as Investigações lógicas de Husserl, constato que aquilo que eu percebo de uma maneira sensível é percebido pelos olhos e ouvidos, pelo olfato e pelo gosto, em suma, pelos órgãos dos sentidos. Ora, e não é a estes órgãos dos sentidos que pertencem as coisas externas, o corpo próprio e as atividades corporais, tais como andar, comer, ver e ouvir? Eis aí a percepção externa! Oposto a isto, temos a percepção de si, na qual as vivências designadas como internamente percebidas são principalmente as "espirituais", tais como pensar, sentir, querer, etc. Somam-se aí, tudo aquilo que, tal como as vivências, é localizado no interior do corpo e não se relaciona com os órgãos externos.

Seria, então, uma uma divisão das percepções por uma divisão dos objetos de percepção? Parece-me que sim. Ao mesmo tempo, isto é enriquecido por uma diferença quanto à maneira pela qual as percepções se originam.

Começo a notar que minha atitude de me esconder dos cegos trouxe a mim um novo olhar acerca da percepção. Desloquei-me nesta tentativa de ser invisível e reparei que me apropriei da noção de percepção de si. Até então acreditava somente na percepção externa e priorizava o que chegava aos meus sentidos. Agora a percepção de si ecoou em meu espírito e mostrou-se, revelou-se de uma maneira muito evidente. Era assim que eu era percebido pelos cegos. Era eu naquele momente uma experiência latente a eles, um amontoado de matéria que ecoava em seus corpos e exigia-Ihes uma resposta. 
Qual resposta? O olhar... E que olhares foram surgindo para mim! Olhares que me especulavam, sabendo de minha muda presença e querendo-me experenciar. E eu ali, sendo uma potência além de seus órgãos de sentidos... Esses olhares pareciam os habitantes da cidade de Bauci descrita por Italo Calvino. Os cegos eram esses habitantes que me observavam do alto com seus binóculos e telescópios. E qual das hipóteses lançadas por Italo Calvino ao falar de Bauci podem explicar meu mudo silêncio invisível? Será que os cegos estavam me odiando? Ou será que eles estavam me respeitando a ponto de evitar meu contato? Ou será que eles amavam a forma como eu era antes deles existirem? Arrisco-me a dizer que eu estava sendo contemplado e que eu mesmo me fascinava pela (minha) própria ausência.

\section{(Fragmento final) Tempo três: entrelaçamentos com o outro}

Fiz um desenho no chão do jardim da biblioteca. Era um círculo e coloquei dentro dele as flores amarelas que haviam caído do ipê. No interior de meu mundo tal desenho/gesto estava sendo repetido. Acolhia os ensinamentos do Escritor e Filósofo e colocava-as dentro de um círculo desenhado em meu íntimo. Este acolhimento passou a ser um gesto que repito em minhas experiências com a cegueira. No Diário de Bordo sempre descrevo o encantamento ao ser guiado pelos cegos. Sinto-me acolhido neste guiar... Parece que eles estão colocando-me num círculo desenhado em seus íntimos. O acolhimento é recíproco. O gesto é o mesmo para ambos, os que guiam e eu que sou guiado. Afinal, quem guia quem?

Levantei-me daquele jardim e, andando em direção ao interior da biblioteca, folheei mais algumas páginas do Diário do Escritor e Filósofo. Sentei-me em uma cadeira e sobre meu colo descansei o Diário de Bordo. Observei-o e pensei nos entrelaçamentos que temos com o outro. Lembrei-me de um espetáculo de dança no qual uma das dançarinas antes de sua coreografia dizia: "Eu e o mundo somos um no outro"... Inevitavelmente, completei a frase : "Eu e o mundo e o outrem somos um no outro, tecidos da mesma carne".

\section{Escrita e método, a margem como possível conclusão?}

Que método é este? Mais do que método existe uma atitude na feitura deste trabalho. Que atitude é esta? O teor deste trabalho de pesquisa passou por caminhos às vezes tortuosos e por escolhas que (re)definiam frequentemente o pesquisar. Tentar adequá-lo à uma narrativa sobre um método possivelmente utilizado é algo que prefiro evitar, pois de tais narrativas sempre desconfiei. Questiono se uma pesquisa pode seguir um trilho rígido, se um pesquisar deve vestir uma camisa de força para não sofrer suas ausências de lucidez. 
Uma pesquisa segue um caminho. Enfrenta variáveis. Tenta (em vão?) dominá-las. Cerca possíveis falhas para não afetar seu resultado final... Fico reticente... E na presente pesquisa? Houve tentações no caminho? Quais desistências aconteceram? As frustações no confronto com objeto de pesquisa delimitaram novos rumos? Em algum momento a pesquisa esteve numa encruzilhada ou rua sem saída?

Ao indagar sobre o método, indago sobre onde se conseguiu chegar, o que foi possível se produzir, como se fez. Enquadramentos em modelos são secundários. A descrição é essencial.

Trago um poema para servir de cenário a quem quiser clarificar a trajetória desta pesquisa. À margem do poema descrevo minha atitude na feitura deste trabalho. Cabe aqui escolher o que ler: o poema, a margem, ou os dois ao mesmo tempo.

\section{O GUARDADOR DE REBANHOS}

(Fernando Pessoa)

XXIV

O que nós vemos das cousas

são as cousas.

Por que veríamos nós uma cousa se houvesse outra?

Por que é que ver e ouvir seria iludirmo-nos

Se ver e ouvir são ver e ouvir?

O essencial é saber ver.

Saber ver sem estar a pensar, Saber ver quando se vê Nem ver quando se pensa.

\section{À MARGEM DO POEMA}

(RODRIGO GONÇALVES)

O principal fio condutor desta pesquisa é indagar o que vemos. Para se aprofundar nesta indagação, é inevitável um olhar mais aguçado para as coisas, vê-las realmente como elas são. Neste movimento, uma atitude fenomenológica estrutura o universo da pesquisa, e, a partir desta opção teórica, ensaiam-se possibilidades de compreender um ver e um não-ver. Se vemos, o que estamos vendo? Se não vemos, o que não vemos?

Compreender a percepção a partir de Merleau-Ponty foi essencial para o desenvolvimento de um marco téórico. Este é o lugar de onde as reflexões da escritura partem. É uma percepção primordial que evoco, uma volta às coisas-mesmas, um ver sem juízos de valor, um movimento prérelfexivo que situa uma ação de descrever aquilo que estamos vendo.

Estudou-se profundamente temas caros à fenomenologia extraindo deles noções acerca do corpo, espaço, 
Isso exige um estudo

profundo,

Uma aprendizagem de

desaprender

E uma sequestração na

liberdade daquele convento

De que os poetas dizem que

as estrelas são as freiras

eternas

$E$ as flores as penitentes

convictas de um só dia,

Mas onde afinal as estrelas

não são senão estrelas

Nem as flores senão flores,

Sendo por isso que the

chamamos estrelas e flores.

XLVIII

Da mais alta janela da minha

casa

Com um lenço branco digo

adeus

Aos meus versos que partem

para a Humanidade.

E não estou alegre nem triste.

Esse é o destino dos versos.

Escrevi-os e devo mostrá-los

a todos

Porque não posso fazer o objeto, percepção, ver e não-ver.

Textos clássicos de Merleau-Ponty

foram estudados, além de uma

aproximação das teorias de Jacques

Derrida sobre escritura e

desconstrução. O trabalho, assim, segue calcado na descrição

fenomenológica. A escritura revela um corpo, desenha uma trajetória a cada página. Histórias são contadas e confrontadas com memórias. Em determinado momento, vê-se que seria fundamental ativar os vividos para estes ecoarem no outro e fazê-lo despertar em seu corpo aquilo que também despertou no meu. As teorias estudadas foram tomando forma e desencadearam textos paralelos entre si os quais ousadamente se tocam e pontuam momentos distintos no trabalho: ora de pura fruição, ora de questionamentos, ora de refexões acerca de nossa atitude em relação ao mundo. Mas, em nenhum momento fugiu-se daquilo que realmente se revela à nós. Foi a descrição fenomenológica que trouxe indagações sobre o (in)visível.

O trabalho não tem a pretensão de provar nada, tampouco de esgotar-se em si mesmo.

O trabalho se mostra àquele que o lê. Reflete uma autoria e procura acionar por meio dos vividos de quem o escreve os vividos de quem o lê. Nesta troca, nesta percepção de outrem, estabelece-se um diálogo e 
contrário

Como a flor não pode

esconder a cor,

Nem o rio esconder que corre,

Nem a árvore esconder que

dá fruto.

Ei-los que vão já longe como que na diligência

E eu sem querer sinto pena

Como uma dor no corpo.

Quem sabe quem os lerá?

Quem sabe a que mãos irão?

Flor, colheu-me o meu destino

para os olhos.

Árvore, arrancaram-me os

frutos para as bocas.

Rio, o destino da minha água

era não ficar em mim.

Submeto-me e sinto-me

quase alegre,

Quase alegre como quem se

cansa de estar triste.

Ide, ide de mim!

Passa a árvore e fica dispersa pela Natureza.

Murcha a flor e o seu pó dura sempre.

Corre o rio e entra no mar e a sua água é sempre a que foi as possibilidades de migração do que a pesquisa descreve para outros campos e áreas de estudo. Eis o destino de um trabalho de pesquisa, eis a única pretensão aqui estabelecida: que as linhas aqui escritas alcem vôos e contagiem o ser humano engajado no mundo.

E, num corpo temporariamente cansado pela trajetória de um pesquisar, dores aparecerem. Dores que devem ser vistas além delas mesmas. Dores que acenam uma despedida, um abandono, um inacabamento. A pesquisa precisa ter uma pausa, ser (re)escrita, lida, comentada, refutada, precisa criar sua própria vida...

A pesquisa estará viva se for lida...

E que sejam feitas as leituras! E que mais indagações surjam! Para um texto estar vivo ele precisa ser desconstruído pelo olhar atento de quem o lê. A minha submissão, ou melhor a submissão desta pesquisa, é

esta: a de ser um elo entre aquilo que supus ver (ou não-ver) com o que um outro supõe também ver (ou não-ver).

E desta maneira ela foi feita. Descrevo para poder indagar. Indago para situar-me no mundo. Percebome percebendo. Procuro estabelecer diálogos em meu íntimo e no íntimo de quem lê o trabalho.

sua. 
Passo e fico, como o Universo.
Aqui fica a pesquisa. Lá vai o

pesquisador. Retornos são

(im)previstos.

\section{Referências}

BOURRIAUD, Nicolas. Estética relacional. São Paulo: Martins Fontes, 2009.

CALVINO, Italo. As cidades invisíveis. São Paulo: Companhia das Letras, 1990.

DERRIDA, Jacques. A escritura e a diferença. São Paulo: Perspectiva, 2009.

HUSSERL, Edmund. Investigações lógicas. Sexta investigação (Elementos de uma elucidação fenomenológica do conhecimento). São Paulo: Nova Cultural, 1996.

MERLEAU-PONTY, Maurice. Conversas - 1948. São Paulo: Martins Fontes, 2004.

MERLEAU-PONTY, Maurice. Fenomenologia da percepção. São Paulo: Martins Fontes, 1994.

MERLEAU-PONTY, Maurice. O homem e a comunicação: A prosa do mundo. Rio de Janeiro: Edições Bloch, 1974.

MERLEAU-PONTY, Maurice. O olho e o espírito. São Paulo: Cosac \& Naify, 2004.

MERLEAU-PONTY, Maurice. O visível e o invisível. São Paulo: Perpsectiva, 2007.

PESSOA, Fernando. O eu profundo e os outros eus. Rio de Janeiro: Nova Fronteira, 2006.

SOKOLOWSKI, Robert. Introdução à fenomenologia. São Paulo: Edicões Loyola, 2004.

\footnotetext{
' Possui graduação em Arquitetura e Urbanismo pela Universidade Federal de Santa Catarina (1999), mestrado em Engenharia de Produção pela Universidade Federal de Santa Catarina (2003) e doutorado em Educação pela Universidade Federal de Santa Catarina (2011). Atualmente é Professor do Departamento de Arquitetura e Urbanismo da Universidade Federal de Santa Catarina. Estuda experiências estéticas e perceptivas e as relações destas com as teorias e práticas projetuais em arquitetura e urbanismo. Tem experiência na área de Arquitetura e Urbanismo, com ênfase em Planejamento e Projetos da Edificação, atuando principalmente nos seguintes temas: projeto arquitetônico, fenomenologia do espaço habitado, experiências de apreensão da arquitetura e da cidade, ensino de projeto.
}

Enviado em: 16 de maio de 2016.

Aprovado em: 12 de julho de 2016. 